\title{
PHYTOREMEDIATION OF WASTEWATER WITH THALIA GENICULATA IN CONSTRUCTED WETLANDS: BASIC POLLUTANTS DISTRIBUTION
}

\author{
GASPAR LÓPEZ-OCAÑA, RAÚL GERMÁN BAUTISTA-MARGULIS, \\ SERGIO RAMOS-HERRERA, CARLOS ALBERTO TORRES-BALCAZAR, \\ ROCÍO LÓPEZ-VIDAL \& LILIANA PAMPILLÓN-GONZÁLEZ \\ Universidad Juárez Autónoma de Tabasco, México
}

\begin{abstract}
Constructed wetlands (CW) are efficient wastewater treatment technologies with low energy consumption. A constructed wetland with horizontal sub-surface flow was designed at a pilot scale involving Thalia geniculate as vegetation, with a wastewater loading rate of $204 \pm 66 \mathrm{~L} /$ day, using gravel as inert medium with a porosity and density of $\mathrm{n}=56.3 \pm 3.5$ and $1666.7 \pm 119.3 \mathrm{~kg} / \mathrm{m} 3$, respectively. The reactor allows the biological treatment of $0.85 \pm 0.05$ and $0.66 \pm 0.05 \mathrm{~m} 3$ of wastewater, with 4.2 days as a hydraulic retention time, favoring the removal of $85 \%$ of the average values of BOD with a $\mathrm{k}$ of -0.43 days- 1 . The pollutant analysis showed a $\mathrm{pH}$ value of $7.5 \pm 0.1$ in the reactor. The temperature ( 30.44 to $28.32^{\circ} \mathrm{C}$ ), the electrical conductivity $(4010$ to $2922 \mu \mathrm{S} / \mathrm{cm}$ ), the turbidity (144 to $17 \mathrm{UTN}$ ) and the bacterial biomass ( 30000 to $2646 \mathrm{mg} / \mathrm{kg}$ ) decreased substantially from inlet to oulet across the reactor. The efficiency of the wastewater treatment in the $\mathrm{CW}$ is notable, nevertheless, keeping the appropiate hydraulic retention time is important in order to fully comply with the maximum permissible limits of $30 \mathrm{mg} / \mathrm{L}$ established in the Mexican environmental legislation (NOM-001-SEMARNAT1996).
\end{abstract}

Keywords: wastewater treatment, macrophytes, subsurface flow, pollutant removal efficiency.

\section{INTRODUCTION}

Constructed wetlands $(\mathrm{CW})$ is not a new technology around the world. They have been studied because of its efficiency to remove organic matter through microbial degradation and settling of colloidal particles, pathogen elimination in domestic water and alternatives in construction design of wastwaster treatment [1]-[7]. Nevertheless, in Mexico and Latin America the applications of CW technology has been incipient, despite the technology has demonstrated the versatility of applications in small and medium urban areas, easy installation, operation and maintance, with highly competitive costs [8]. The most common type of constructed wetlands are the free water surface constructed wetlands (FWS-CW) and the horizontal subsurface flow constructed wetlands (HF-CW).

In this context, it is estimated that $\mathrm{CW}$ plants require two or three growing seasons to achieve the maxium removal effiency [9]. The vegetation in the CW is important because the pollutant removal through direct assimilation into their tissues provides an adequate medium for microbial activity through the transport of oxygen to the rhizosphere, stimulating the aerobic degradation of organic matter and nitrifying bacteria growth [10], [11]. It has also been shown that the efficiency removal of contaminants depends on the support material and the hydraulic retention time (HRT) [12]. The communities interested in adopting this technology must develop $\mathrm{CW}$ based on local parameters [13], since the design can be influenced by hydrometeorological factors, which must be taken into account for the operation of the system [14], [15].

In an experimental study with vertical flow constructed wetlands (VF-CW) a bacterial culture of fungi and actinomycetes was used [4]. It was concluded that microorganisms play a key factor in the decontamination process and can be an indicator in the removal of 
chemical oxygen demand (COD), biochemical oxygen demand (BOD), total nitrogen (TN), total phosphorus (TP) and total suspended solids (TSS). A train of treatment was also evaluated, consisting in three $\mathrm{CW}$ connected in series involving a sub-superficial flow (HF $\mathrm{CW}$ ), using vegetation such as reed (Scirpus americanus), enea (Typha latifolia) and water lilies (Eichhornia crassipes). The system was stabilized in 44 days, having an HRT of 15 days in each $\mathrm{CW}$, reporting high removal efficiencies of COD $(71 \%)$, calcium $(91 \%)$, chloride $(77 \%)$, nitrite $(82 \%)$, ammonium $(99.9 \%)$, phosphate $(77 \%)$ except for nitrate ion $(36 \%)$ and electrical conductivity (93\%) [9].

The effect on the removal of ammoniacal nitrogen in contaminated water was also studied from the Erh-Ren River in southeastern Taiwan [16]. The evaluation was performed through an experimental control and coupled HF and FWS, CW systems connected in series. Wetland vegetation such as Chinese grass (Pennisetum alopecuroides L.) and Pacific Island grass (Miscanthus floridulus) were involved in a HF-CW and FWS-CW respectively. These species did not survive to the winter due to the low temperature and the high salinity of the water, due to the salt intrusion from the sea water into the river. As a consequence, common reed (Phragmites australis) in both CW systems was shown, with an initial density of 2 plants per $\mathrm{m}^{2}$ and growing around 100 plants per $\mathrm{m}^{2}$ after 3 months. The control system during the experiment worked without species, concluding that season time affected the $\mathrm{CW}$ performance, particularly for the removal of ammoniacal nitrogen.

Mexico has $110 \mathrm{CW}$ systems throughout the country, three of them in the state of Tabasco, and only one operates in the Municipality of Centro at $64 \%$ of its capacity, because it was designed to treat a flow of $0.125 \mathrm{~m}^{3} / \mathrm{s}$ and currently operates with a flow of $0.080 \mathrm{~m}^{3} / \mathrm{s}$ [17]. In Tabasco-Mexico, the coverage of water treatment is low since 60 out of 93 wastewater treatment plants are known for their defficient performance operation. There is a notable predominance of conventional technologies and primary wastewater system, whose treatments are inefficient, and the costs have not yielded the expected results.

In this respect, it is necessary to look for economic treatments that are easy to operate and appropriate for the climatic conditions and natural resources of the region, presenting technical and economical advantages over chemical treatment methods [17]. The objective of the current research work was to evaluate the phytoremediation potential of wastewater with Thalia geniculata in a $\mathrm{CW}$, analizing the basic pollutan distribution and degradation at a pilot scale. CWs built in Tabasco consider HF and FWS system operated mainly with introduced species, such as Thypa latifolia. In the case of Thalia geniculata, it is also a native specie from Tabasco, but not studied so far and present advantages from introduced species in CW systems.

\section{MATERIALS AND METHODS}

\subsection{Location of the pilot-scale CW}

The experimental HW-CW was installed at the Division Academica de Ciencias Biologicas (DACBiol), which is a campus from the Universidad Juarez Autonoma de Tabasco. The vegetation was collected in swampy areas from the Municipality of Centro, Tabasco.

\subsection{CW design characteristics}

The reactor is $2.5 \mathrm{~m}$ long $\times 1.2 \mathrm{~m}$ wide $\times 1 \mathrm{~m}$ high [18]. The preparation began with the cleaning of the corrosion areas using an anticorrosive primer (white enamel finish layer) was applied in the external part. In the internal part, waterproofing of acrylic paste based on resins 
and mineral fillers ( $1 \mathrm{~cm}$ thick) was applied. Afterwards, an elastomeric waterproofing layer was applied with a textile fiber reinforcing the internal part to avoid possible filtrations (five layers were placed). Once the reactor was waterproofed, all accessories, 1-inch hydraulic polyvinylide (PVC) pipes and fittings (valves, elbows, T's, connectors, etc.) were installed for the supply and distribution of the wastewater. For natural aeration, internal sampling points were placed. Finally, $50 \mathrm{~cm}$ of mixed gravel was placed in the reactor, and then proceed for the stabilization phase of vegetation.

\subsection{Planting and stabilization of vegetation}

The vegetation was placed into the gravel support medium. The stem size on the surface was $10 \mathrm{~cm}$ long and roots were placed $15 \mathrm{~cm}$ below the surface [8]. The reactor was fed with clean water at the beginning, maintaining a level of $40 \mathrm{~cm}$ of water for stabilization of the vegetation [19]. Thereafter, wastewater from the carcamus of the DACBiol was added to the CW. The stabilization phase in CW lasted six months from February to July 2016.

\subsection{Hydraulic retention time, removal efficiency and degradation rate}

In the reactor, a mixed gravel support medium (crushed rock from the Teapa River, southern region of Tabasco) was placed and the hydraulic retention time (HRT) was calculated with the operation flow of the wastewater [8]

$$
\mathrm{HRT}=\mathrm{nd} \mathrm{A} / \mathrm{Q},
$$

where $\mathrm{n}$ is the porosity, $\mathrm{d}$ is the heigh of the support medium, $\mathrm{A}$ is the cross section of the reactor and $\mathrm{Q}$ is the water flowrate.

$$
\eta=\left[\left(C_{1}-C_{2}\right) / C_{1}\right] \times 100
$$

where $\eta$ represents the removal efficiency in $\%, C_{1}$ the wastewater influent concentrationand $C_{2}$ the wastewater effluent concentration.

The behavior of wastewater is a first order kinetic reaction, the degradation rate $k$ was estimated with the following eqn (3).

$$
\mathrm{K}_{\mathrm{o}}=-\ln \left(\mathrm{Cn} / \mathrm{C}_{\mathrm{o}}\right) / \tau
$$

where $\tau=$ retention time for BOD removal, $\mathrm{Cn}=\mathrm{BOD}$ influent concentration of the reactor " $\mathrm{n}$ " (mg/L), Co = influent concentration, $\mathrm{K}_{\mathrm{o}}=$ degradation constant.

\subsection{Wastewater characterization}

In order to study the variables of the wastewater, sampling points were established and sampled throughout the reactor (Table 1, Fig. 1). Three samples were taken by triplicate per day during 5 days. For the kinetic study of the BOD, the influent and effluent of the reactor was monitored, taking a simple daily sample for 7 days, and up to one year of operation in the reactor. 
Table 1: Wastewater methods of analysis applied for control parameter determinations.

\begin{tabular}{l|l}
\hline Parameter & Environmental regulation in Mexico \\
\hline Temperature & NMX-AA-007-SCFI-2000 \\
Turbidity & NMX-AA-038-SCFI-2001 \\
Electrical conductivity & NMX-AA-093-SCFI-2000 \\
pH & NMX-AA-008-SCFI-2000 \\
Biological oxygen demand & NMX-AA-028-SCFI-2001 \\
Total volatile solids & NMX-AA-034-SCFI-2001 \\
\hline
\end{tabular}

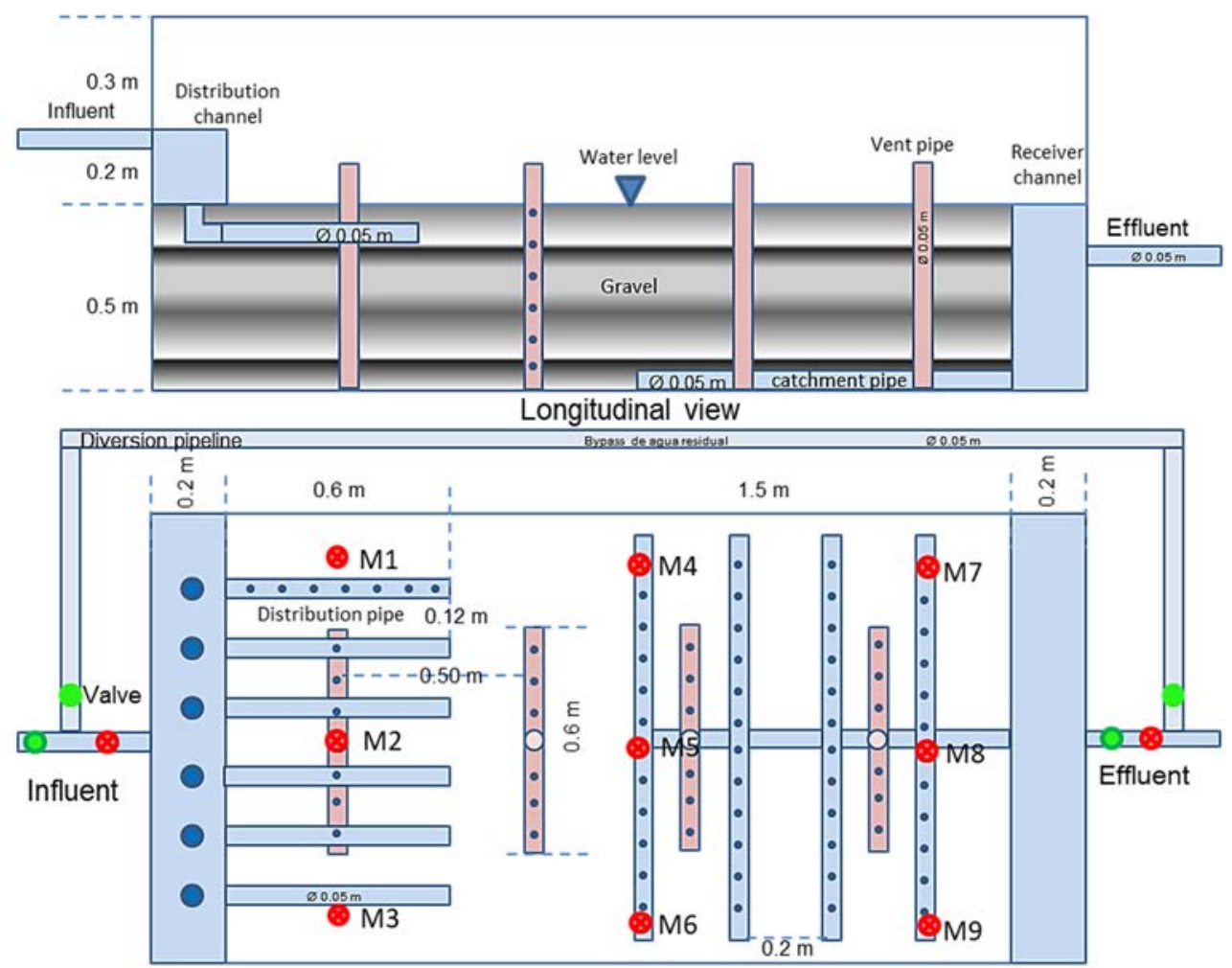

Plan view

Figure 1: The red points from M1 to M9 indicate the sampling point in the Subsurface Horizontal Flow - Constructed Wetland (HF-CW).

\subsection{Biomass on the support medium}

The biomass, refering to the quantity of microorganisms on the rocks was determined by gravimetry adapting the total volatile solids (SVT) method to a sample of the support medium at each sampling point (Fig. 1). Each sample considers the density and porosity of the system [21]. 


\subsection{Modeling of the pollutants distribution}

To achieve the modeling, the daily average of each sampling point referring to variables such as temperature, turbidity, electric conductivity, $\mathrm{pH}$ and biomass were monitored and analyzed. The pollutants distribution inside the reactor was plotted using the software Surfer 8.0 [22], which allows the determination of the spatial distribution within a coordinate system based on a linear interpolation and a quadratic diagram (isoconcentration map).

\section{RESULTS AND DISCUSSION}

\subsection{Hydraulic retention time (HRT)}

The HF-CW was designed to operate with $200 \mathrm{~L} /$ day. However, when performing the corresponding gaugings and the volumetry of the wastewater flowrate, the HRT was estimated in 4.2 days. This value fulfilled the design criteria for CW established by several authors [8], [13], [15], [19] Fig. 2 shows the HRT at different operating wastewater flowrates. The average operating flow in this period was $204 \pm 66 \mathrm{~L} /$ day, with $108 \mathrm{~L} /$ day and $370 \mathrm{~L} /$ day, as minimum and maxium operation wastewater flow values, respectively.

\subsection{Degradation rates and kinetic coefficient}

When the wastewater flowrate exceeded $200 \mathrm{~L} / \mathrm{d}$, the HRT was observed to decrease. Therefore, the wastewater did not have enough time to be in contact with the microorganisms and vegetation, resulting in a low degradation. In order to analyse the influence of design parameters (loading rate, flow and temperature) on the degradation of pollutants in the wastewater, the removal of BOD was measured. It is important to note that facultative microorganisms eliminate part of the BOD through biological and physic process, mainly. The pollution removal rate in wastewater is related to HRT and temperature. The temperature

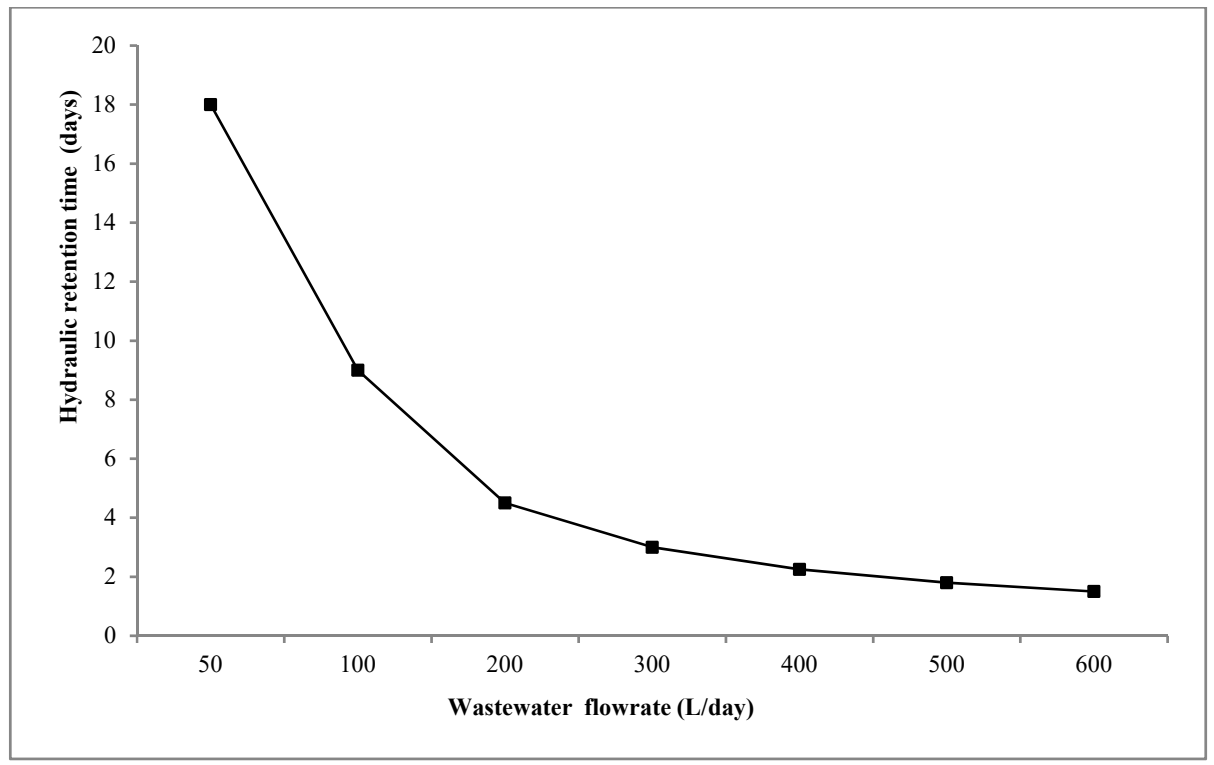

Figure 2: HRT for different operating wastewater flowrates in the HF-CW. 
during the evaluation was $27^{\circ} \mathrm{C}$ on average. The HRT was 4.5 days and $k$ was calculated in -0.43 days $^{-1}$. The Mexican water regulations established a daily discharge average of $75 \mathrm{mg} / \mathrm{L}$ for the HRT parameter. This value can be achieved between the fourth and fifth day of operation, as shown in Fig. 3 [23].

The HF-CW (HRT $=6$ days) removed nearly $90 \%$ of the organic pollutants in the wastewater and comply with the most stringent criteria established by the Mexican regulations for the aquatic life protection. Similar results were reported elsewhere [24], concluding that 8 days of HRT is adequate for the removal of organic matter at temperatures above $25^{\circ} \mathrm{C}$. The kinetic degradation behavior of the organic matter in the HF-CW is described as a first order kinetic (Table 3).

\subsection{BOD removal efficiency}

The maximum BOD removal efficiency was $92.8 \%$. The average removal efficiency was found to be between 80 and $85 \%$. Unlike the operation of other experimental reactors in series [19], [25], the current reactor is setup with a primary and secondary treatment, satisfying the regulations for wastewater discharge to rivers for urban public use $(75 \mathrm{mg} / \mathrm{L})$. Furthermore, it complies occasionally to the aquatic life protection limit $(30 \mathrm{mg} / \mathrm{L})[23]$.

\subsection{Spatial distribution of pollutants in the HF-CW}

The basic parameters of pollutants monitored in wastewater for the spatial distribution analysis can be seen in Table 3 .

Regarding the $\mathrm{pH}$ values, some differences were observed in the spatial distribution, but the values remained in the neutral range of 7.2-7.9 (Fig. 5). This variation may be explained by the type of substrate and biofilm employed in this investigation [25]. The temperature was $29.2 \pm 0.8^{\circ} \mathrm{C}$ on average, with variation from the input to the output of the reactor with 30.5 to $28.1^{\circ} \mathrm{C}$, respectively (Fig. 6). This temperature behaviour favors the growth and the stabilization of mesophilic microorganisms [26]. The electrical conductivity values were measured around $3442.7 \pm 408.0 \mu \mathrm{S} / \mathrm{cm}$, in compliance to the regulation for agricultural

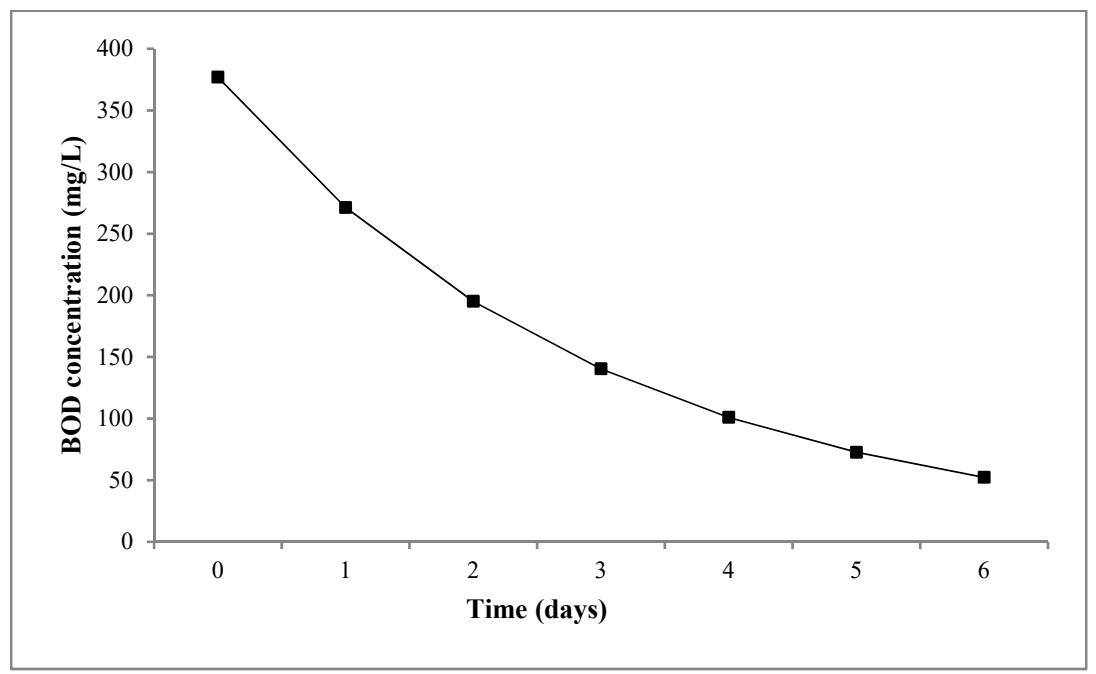

Figure 3: Degradation of organic matter in the HF-CW with Thalia geniculata vegetation. 
Table 2: Estimation of the kinetic degradation constants evaluated in the HF-CW with Thalia geniculata vegetation.

\begin{tabular}{|c|c|c|c|c|}
\hline Days & BOD influent (mg/L) & $\begin{array}{c}\text { BOD effluent } \\
(\mathrm{mg} / \mathrm{L})\end{array}$ & $\mathrm{k}\left(\mathrm{d}^{-1}\right)$ & $\eta(\%)$ \\
\hline 1 & 375.50 & 66.20 & -0.39 & 82.4 \\
2 & 369.40 & 65.30 & -0.39 & 82.3 \\
3 & 403.20 & 66.50 & -0.40 & 82.5 \\
4 & 437.10 & 65.90 & -0.42 & 84.9 \\
5 & 391.70 & 43.30 & -0.49 & 88.9 \\
6 & 407.70 & 29.50 & -0.58 & 92.8 \\
7 & 254.20 & 50.50 & -0.36 & 80.1 \\
Average & 376.97 & 55.31 & -0.43 & 85.3 \\
\hline
\end{tabular}

Table 3: Basic pollutant parameters measured in wastewater for the HF-CW.

\begin{tabular}{|c|c|c|c|c|c|c|c|c|c|c|}
\hline Days & Parameters & M1 & M2 & M3 & M4 & M5 & M6 & M7 & M8 & M9 \\
\hline \multirow{4}{*}{1} & $\mathrm{pH}$ & 7.9 & 7.7 & 7.5 & 7.8 & 7.6 & 7.5 & 7.8 & 7.4 & 7.4 \\
\hline & Temperature $\left({ }^{\circ} \mathrm{C}\right)$ & 32.3 & 32.2 & 31.2 & 29.4 & 30.9 & 31.3 & 29.6 & 29.5 & 29.5 \\
\hline & $\begin{array}{l}\text { Conductivity } \\
(\mu \mathrm{S} / \mathrm{cm})\end{array}$ & 4160 & 4010 & 3770 & 3450 & 3640 & 3280 & 2760 & 2870 & 2530 \\
\hline & Turbidity (NTU) & 226 & 176 & 176 & 165 & 171 & 110 & 23.1 & 17.6 & 6.9 \\
\hline \multirow{4}{*}{2} & $\mathrm{pH}$ & 7.5 & 7.5 & 7.5 & 7.6 & 7.5 & 7.5 & 7.5 & 7.4 & 7.2 \\
\hline & Temperature $\left({ }^{\circ} \mathrm{C}\right)$ & 30.5 & 30.8 & 29.7 & 27.2 & 27.5 & 26.7 & 26.7 & 25.1 & 25.1 \\
\hline & $\begin{array}{l}\text { Conductivity } \\
(\mu \mathrm{S} / \mathrm{cm})\end{array}$ & 4010 & 3680 & 3890 & 3070 & 2370 & 2950 & 2300 & 2240 & 2520 \\
\hline & Turbidity (NTU) & 195 & 196 & 178 & 103 & 95 & 90 & 89 & 72 & 68 \\
\hline \multirow{4}{*}{3} & $\mathrm{pH}$ & 7.4 & 7.4 & 7.4 & 7.6 & 7.6 & 7.6 & 7.6 & 7.6 & 7.7 \\
\hline & Temperature $\left({ }^{\circ} \mathrm{C}\right)$ & 30.0 & 29.3 & 29.6 & 29.7 & 29.1 & 29.1 & 28.8 & 28.3 & 29 \\
\hline & $\begin{array}{l}\text { Conductivity } \\
(\mu \mathrm{S} / \mathrm{cm})\end{array}$ & 3950 & 3920 & 3920 & 2710 & 4020 & 3840 & 4000 & 3740 & 3640 \\
\hline & Turbidity (NTU) & 42.0 & 42.6 & 42.6 & 12.4 & 12.5 & 8.71 & 3.64 & 2.8 & 2.1 \\
\hline \multirow{4}{*}{4} & $\mathrm{pH}$ & 7.3 & 7.5 & 7.8 & 7.4 & 7.5 & 7.8 & 7.4 & 7.6 & 7.8 \\
\hline & Temperature $\left({ }^{\circ} \mathrm{C}\right)$ & 29.9 & 29.2 & 29.5 & 29.8 & 29.3 & 29.4 & 29.6 & 29.1 & 29.4 \\
\hline & $\begin{array}{l}\text { Conductivity } \\
(\mu \mathrm{S} / \mathrm{cm})\end{array}$ & 3930 & 3930 & 3940 & 3940 & 4080 & 4000 & 3910 & 4080 & 3650 \\
\hline & Turbidity (NTU) & 38.7 & 35.8 & 39.7 & 10.7 & 10.7 & 11.5 & 2.95 & 3.49 & 3.67 \\
\hline \multirow{4}{*}{5} & $\mathrm{pH}$ & 7.3 & 7.3 & 7.3 & 7.7 & 7.7 & 7.7 & 7.7 & 7.6 & 7.6 \\
\hline & Temperature $\left({ }^{\circ} \mathrm{C}\right)$ & 29.5 & 29.2 & 30.2 & 28.7 & 28.9 & 29.1 & 28.8 & 28.8 & 28.6 \\
\hline & $\begin{array}{l}\text { Conductivity } \\
(\mu \mathrm{S} / \mathrm{cm})\end{array}$ & 4000 & 4020 & 3860 & 3190 & 3190 & 3040 & 2300 & 2350 & 2270 \\
\hline & Turbidity (NTU) & 220 & 227 & 210 & 81 & 83 & 76 & 3.1 & 2.57 & 6.73 \\
\hline
\end{tabular}

irrigation in Mexico. Salinity is considered low, with values from 4000 to $2900 \mu \mathrm{S} / \mathrm{cm}$ (Fig. 7). The HF-CW reduced the salinity of the wastewater; thus water is suitable to be used without restriction for crops irrigation of [27]. 
Turbidity shows a significant decrease from influent to effluent in the HF-CW. This behavior is associated with Thalia geniculata vegetation, which is very effective at removing up to $87 \%$ of the sediments (Fig. 8). Finally, the biomass adhered to the support medium presented the highest concentration of microorganisms at the reactor inlet and decreasing significantly at the reactor outlet. The biomass concentration was found to be higher than $33,000 \mathrm{mg} / \mathrm{kg}$ ( $\mathrm{mg}$ of biomass on $\mathrm{kg}$ of rock "medium support") in the influent and reaching values of $3000 \mathrm{mg} / \mathrm{kg}$ at the end of the reactor. The support medium has a diameter of $2.8 \pm$ $0.8 \mathrm{~cm}$, porosity $\mathrm{n}=56.3 \pm 3.5$ and density of $1666.7 \pm 119.3 \mathrm{~kg} / \mathrm{m}^{3}$. These characteristics allow a water volume of $0.85 \pm 0.05 \mathrm{~m}^{3}$ and $0.66 \pm 0.05 \mathrm{~m}^{3}$ of gravel within the HF-CW.

A HF-CW experimental study reported BOD removals greater than $90 \%$ with Typha and Phragmites vegetation [28]; while a removal efficiency of 79\% was observed with Typha latifolia for combined HF reactors [29]. Similar removal efficiencies for BOD (80\%) were reported with Typha and Phragmites in the second year of evaluation of an HF-CW [30]. In this study, Thalia genicualata vegetation showed a high removal efficiency of BOD $(85 \%)$. The BOD removal in a CW is generally high because the organic components are degraded aerobically and anaerobically by the bacteria adhered to the roots and rhizomes of the plants with the porous medium [31]. The water treatment in a HF-CW with a HRT of 6 days and temperatures around $-28^{\circ} \mathrm{C}$ is sufficient to obtain removals greater than $90 \%$. Similar results were concluded for 8 days of HRT for the removal of organic matter at temperatures above $15^{\circ} \mathrm{C}$ [24]. Thalia geniculata is not frecuently cited in the literature, however in this study it is demonstratred the great potential for wastewater treatment from this native vegetation in the tropical region of Mexico. The most important effects of emerging macrophytes in wastewater treatment are plant tissue, wind speed reduction that supports the sedimentation of suspended solids, filtering effect or adherence of microorganisms to the roots plants that can be a significant route for the elimination of nutrients, especially under low loading rates [32]. Therefore, Thalia geniculata is highly efficient for the removal of basic pollutants in the treatment of domestic wastewater.

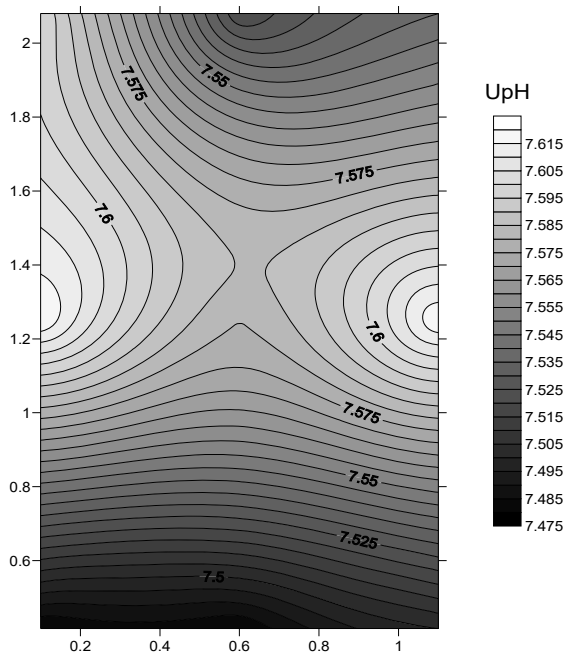

Figure 4: pH spatial distribution.

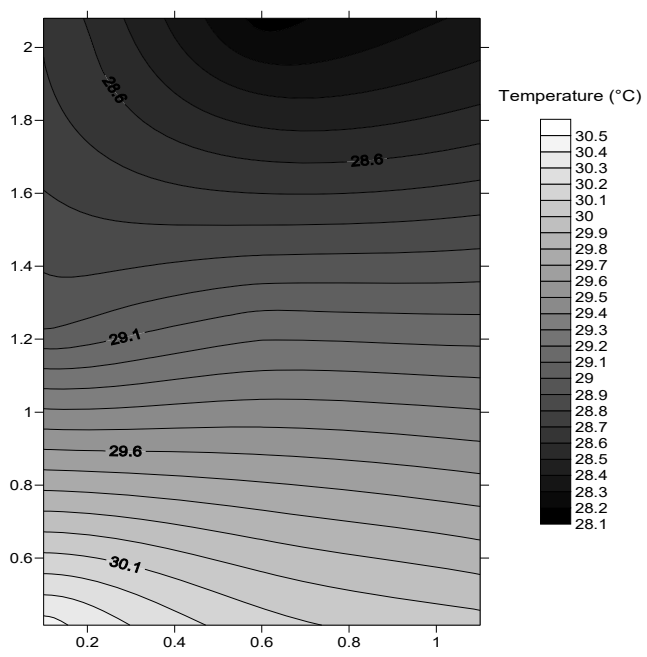

Figure 5: Temperature spatial distribution. 


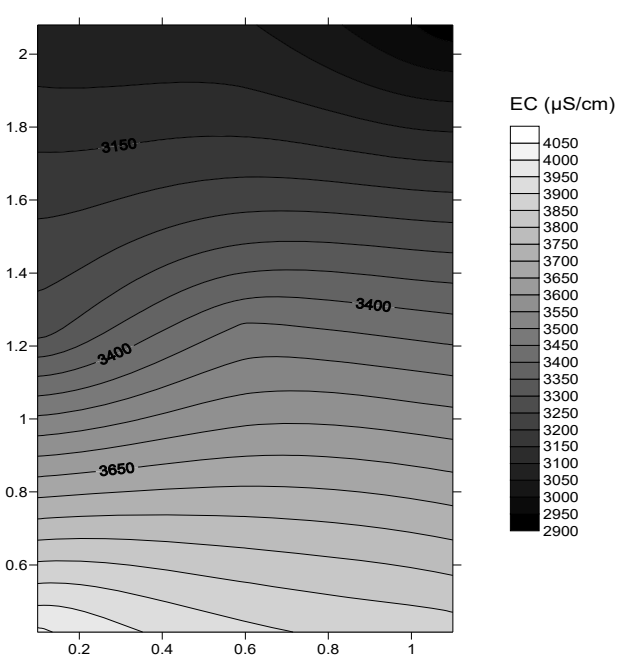

Figure 6: Electrical conductivity spatial distribution.

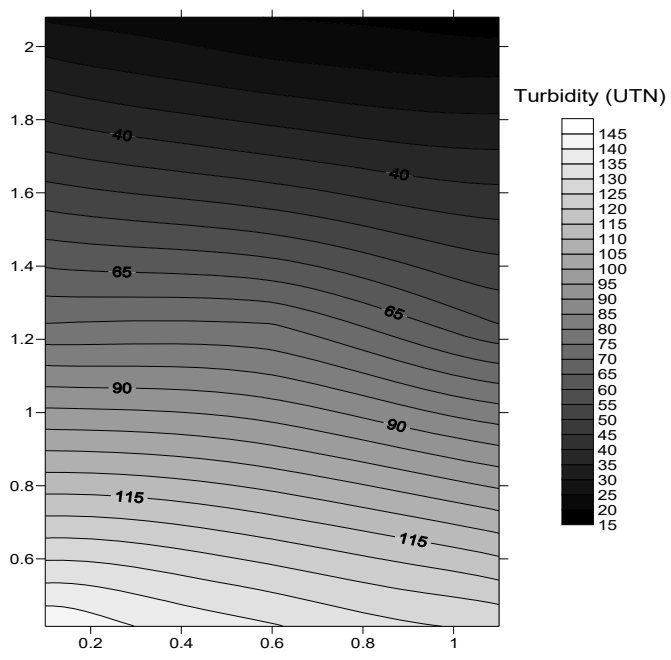

Figure 7: Turbidity spatial distribution.

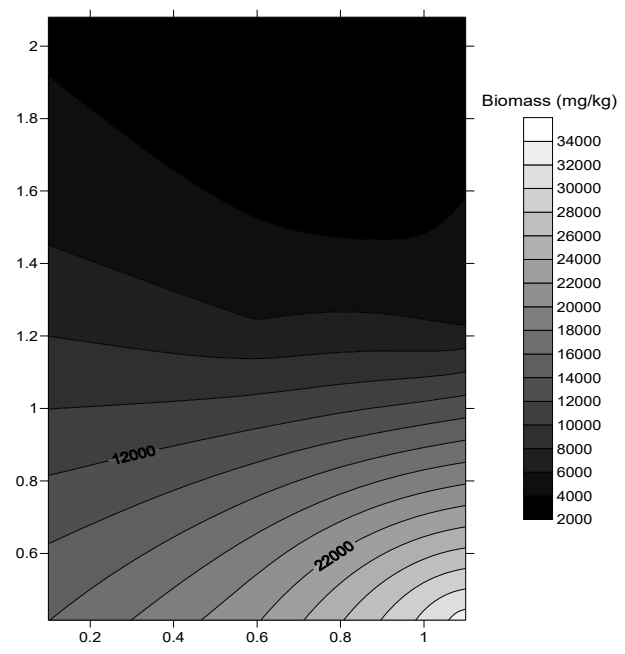

Figure 8: Biomass spatial distribution.

\section{CONCLUSIONS}

Thalia geniculata vegetation was found to be quite efficient for wastewater treatment in a subsurface flow constructed wetland (HF-CW) with $85 \%$ of BOD removal. The daily average temperature $\left(28^{\circ} \mathrm{C}\right)$ showed a $k$ of -0.43 days $^{-1}$, promoting the pollutant removal, similarly as a secondary water treatment. The support medium influenced significantly the microorganism's fixation, meaning that the mixed gravel employed was appropriate for the treatment. 
From the operation standpoint, the experimental reactor attained the highest removal efficiencies of basic contaminants when the HRT ranged from 4.2 to 6 days. The experimental design of the $\mathrm{HF}-\mathrm{CW}$ proposed in this research complied with the environmental regulation for water standards in Mexico $(75 \mathrm{mg} / \mathrm{L})$.

\section{REFERENCES}

[1] Reed, S.C., Crites, R.W. \& Middlebrooks, E.J., Natural Systems for Waste Management and Treatment. 2nd ed., McGraw Hill Co.: New York, NY, 1995.

[2] García, J., Ruiz, A. \& Junqueras, X., Depuración de aguas residuales urbanas mediante humedales construidos. Tecnología del Agua, 165, pp. 58-65, 1997.

[3] García, M., Bécares, E., Soto, F. \& de Luis, E., Macrófitos en la depuración de aguas residuales, su función en la eliminación de bacterias. Tecnología del Agua, 185, pp. 64-67, 1999.

[4] Liang, W., Zhen-bin, W., Shui-Ping, C., Qiao-Hong, Z. \& Hong-Ying, H., Roles of substrate microorganisms and urease activities in wastewater purification in a constructed wetland system. Ecological Engineering, 21, pp. 191-195, 2003.

[5] Pigem, J.O., Marzo, R., de la Peña, J.L. \& Llagostera, R., Infiltración/Percolación y humedales como tratamientos blandos en la depuración de aguas residuales. Tecnología del Agua, 186, pp. 48-53, 1999.

[6] Soto, F., Bécares, E., García, M. \& de Luis, E., Macrófitos en la depuración de aguas residuales. Su función en la eliminación de nutrientes. Tecnología del Agua, 185, pp. 68-72, 1999.

[7] Llagas, C.W.A. \& Guadalupe, G.E., Diseño de humedales artificiales para el tratamiento de aguas residuales en la UNMSM. Revista del Instituto de Investigación FIGMMG, 15(17), pp. 85-96, 2006.

[8] Crites, R.W., Tchobanoglous. G., Small and Decentralized Wastewater Management Systems, McGraw Hill Co.: New York, NY, 2000.

[9] Ramos, E.M.G., Rodríguez, S.L.M. \& Martínez, C.P., Uso de Macrófitos acuáticas en el tratamiento de aguas para el cultivo de maíz y sorgo. Hidrobiología, 17, pp. 7-15, 2007.

[10] Moshiri, G.A., Constructed Wetlands for Water Quality Improvement, Lewis Publishers: USA, p. 615, 1993.

[11] Brix, H., Functions of macrophytes in constructed wetlands. Wat. Sci. Tech., 29(4), pp. 45-53, 1994.

[12] Padrón-López, R.M., Depuración de aguas residuales domésticas a través de humedales artificiales de flujo vertical en zonas Trópico-Húmedas. Tesis Maestría en Ciencias Ambientales UJAT, 2005.

[13] Kivaisi, A.K., The Potential for constructed wetlands for wastewater treatment and reuse in developing countries: a review. Ecological Engineering, 16, pp. 545-560, 2000.

[14] Folch, M., Huertas, E. \& Salgot, M., Zonas Húmedas Artificiales como tratamiento de aguas residuales en pequeños núcleos urbanos: El caso de ELS Hostalets de Pierola (Barcelona). Manual de agua potable para comunidades rurales, reuso y tratamiento avanzados de aguas residuales domésticas, capitulo, 17, pp. 199-205, 2000.

[15] USEPA. Office of Research and Development Cincinnati, Ohio, EPA/625/R-99/010, Design Manual: Constructed wetlands treatment of municipal wastewater. Sept. 2000.

[16] Jing, S.R. \& Lin, Y.F., Seasonal effect on ammonia nitrogen removal by constructed wetlands treating polluted river water in southern Taiwan. Environmental Pollution, 127, pp. 291-301, 2004. 
[17] Comisión Nacional del Agua (CONAGUA). Inventario Nacional de Plantas Municipales de Potabilización y de Tratamiento de Aguas Residuales en Operación. Subdirección General de Agua Potable, Drenaje y Saneamiento. Diciembre 2015. www.gob.mx/conagua.

[18] López-Ocaña G. et al., Diseño de sistemas experimentales de humedales artificiales de flujo libre y subsuperficial. Perspectiva Científica desde la UJAT. ISBN: 978607-606172-5, pp. 133-146, 2014.

[19] CONAGUA, Manual de plantas de tratamientods de aguas residuales. Lechos de Hidrófitas, capítulo 5. Subdirección General de Agua Potable, Drenaje y Saneamiento. Diciembre 2007.

[20] Chung, A.K.C., Wu, Y., Tam, N.F.Y. \& Wong, M.H., Nitrogen and phosphate mass balance in a sub-surface flow constructed wetland for treating municipal wastewater. Ecological Engineering, 32, pp. 81-89, 2008. http://dx.doi.org/10.1016/ j.ecoleng.2007.09.007.

[21] McCabe, W.L., Smith, J.C. \& Harriot, P., Operaciones Unitarias en Ingeniería Química. Mc Graw Hill, 1112. Cuarta Edición, 1991.

[22] Surfer 8.0. Powerful Contouring, Gridding, and 3D Surface Mapping Software for Scientists and Engineers. Surfer ${ }^{\mathbb{B}}$ Software.

[23] NOM-001-SEMARNAT-1996, Que establece los límites máximos permisibles de contaminantes en las descargas de aguas residuales en aguas y bienes nacionales. Secretaría de Medio Ambiente, Recursos Naturales y Pesca. Diario Oficial de la Federación. 23 de Abril de 2003.

[24] Akratos, S.C. \& Tsihrintzis, A.V., Effect of temperature, HRT, vegetation and porous media on removal efficiency of pilot-scale horizontal subsurface flow constructed wetlands. Ecological Engineering, 29, pp. 173-191, 2007. http://dx.doi.org/ 10.1016/j.ecoleng.2006.06.013.

[25] Jiménez-López, E.C., Wastewater treatment by constructed wetlands with thalia geniculata and paspalum paniculatum in a tropical system of Mexico. Int. J. Sus. Dev. Plann., 12(1), pp. 42-50, 2017. DOI: 10.2495/SDP-V12-N1-42-50.

[26] Kadlec, R.H. \& Knight, R., Treatment Wetlands, Lewis Publishers: Boca Raton, FL, 1996.

[27] Silva, J., Torres, P. \& Madera, C., Reuso de aguas residuales domésticas en agricultura: Una revisión. Agro Col., 2, pp. 347-359, 2008.

[28] Morari, F., Giardini, L., Municipal wastewater treatment with vertical flow constructed wetlands for irrigation reuse. Ecological Engineering, 35, pp. 643-653, 2009. http://dx.doi.org/10.1016/j.ecoleng.2008.10.014.

[29] Karathanasis, A.D., Potter, C.L. \& Coyne, M.S., Vegetation effects on fecal bacteria, BOD, and suspended solid removal in constructed wetlands treating domestic wastewater. Ecological Engineering, 20, pp. 157-169, 2003. http://dx.doi.org/ 10.1016/S0925-8574(03)00011-9

[30] Solano, M.L., Soriano, P. \& Ciria, M.P., Constructed wetlands as a sustainable solution for wastewater treatment in small villages. Biosystem Engineering, 87(1), pp. 109118, 2004.

[31] Abidi, S., Kallali, H., Jedidi, N., Bouzaiane, O. \& Hassen, A., Comparative pilot study of the performances of two constructed wetland wastewater treatment hybrid systems. Desalination, 246, pp. 370-377, 2009. http://dx.doi.org/10.1016/j.desal.2008.03.061.

[32] Vymazal, J., Emergent plants used in free water surface constructed wetlands: a review. Ecological Engineering, 61, pp. 582-592, 2013. http://dx.doi.org/10.1016/ j.ecoleng.2013.06.023. 